\title{
Facies Analysis and Depositional Environments of the Euphrates Formation Between Fuhaimi and Al-Qaim Valleys, in Western Desert-Iraq
}

\author{
Abdul-Aziz M. Al-Hammdani \\ Department of Geology \\ College of Science \\ Mosul University
}

\author{
Salim Q. Al-Naqib Kotayba T. Al-Youzbaki \\ Dams and Water Resources \\ Research Centre \\ Mosul University
}

(Received 15/12/ 2002 , Accepted 15/5/ 2004)

\begin{abstract}
The study involves the Euphrates Formation in the area between Fuhaimi and AlQaim valleys in the western desert of Iraq. The Formation was divided into six informal units depending on various lithological properties. Facies analysis reveals the presence of the following microfacies, from bottom to top respectively; pelletal lime packstone, pellitoidal lime grainstone, oolitic lime grainstone, benthonic lime packstone and dolomitized lime mudstone microfacies. These microfacies, in addition to some geochemical properties were used to interpret the depositional environments, which are ranging from shelf, low water energy restricted and lagoonal environment to relatively high water energy open marine.
\end{abstract}

\section{النحلال السحفي والبيئلت النرسيبية لتكون الفرات بين واليي الفحيي والفأم في المحراء الغربية -الهراق}

\section{الملغص}

تشمل الدرلسة الحالية تكوين الفرات في المطقة المحصورة بين وادي ي الفحيم مي والق ائم ف مي الصحراء الغربية من العراق. وقد قم التكوين الهست وحدات طقبية أعتمادَ على الصفلت الـ صخارية

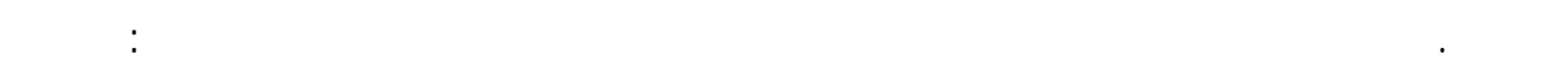

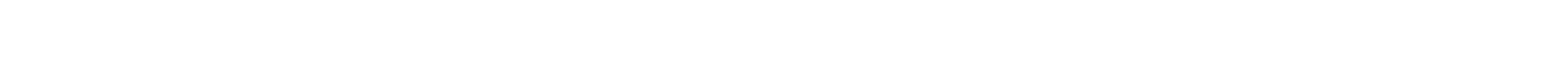

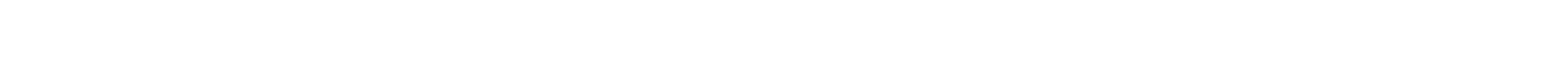
الطيني المتدلمت.

لستخدت هذه السحنات فضلاً عن بعض خصائصها الجيوكيميائية لسلساً لقفير البيئلت الترس ـيبية

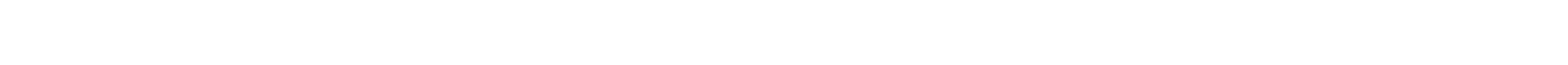
مفتوحة ذات طاقة ميل عالية نسبياً. 


\section{INTRODUCTION}

The study area extends from Fuhaimi Valley East of Anah town to Al-Qaim valley (Fig. 1). Geomorphologically, the area is regarded as hilly topographic terrain forming continuous ridges of relatively low relief. Many valleys with various sizes dissected the area in NE-SW direction, oriented towards the Euphrates River.

Fuhaimi valley has a length of about $(14 \mathrm{Km})$ and $(4 \mathrm{Km})$ average width, whereas Al-Qaim valley has about $(9 \mathrm{Km})$ length and $(2-3 \mathrm{Km})$ width range, although it becomes narrow near the General Establishment of Phosphate. The two studied valleys form dendritic drainage pattern. The main objective of this work is to interpret the depositional environment of the Euphrates Formation in the studied area.

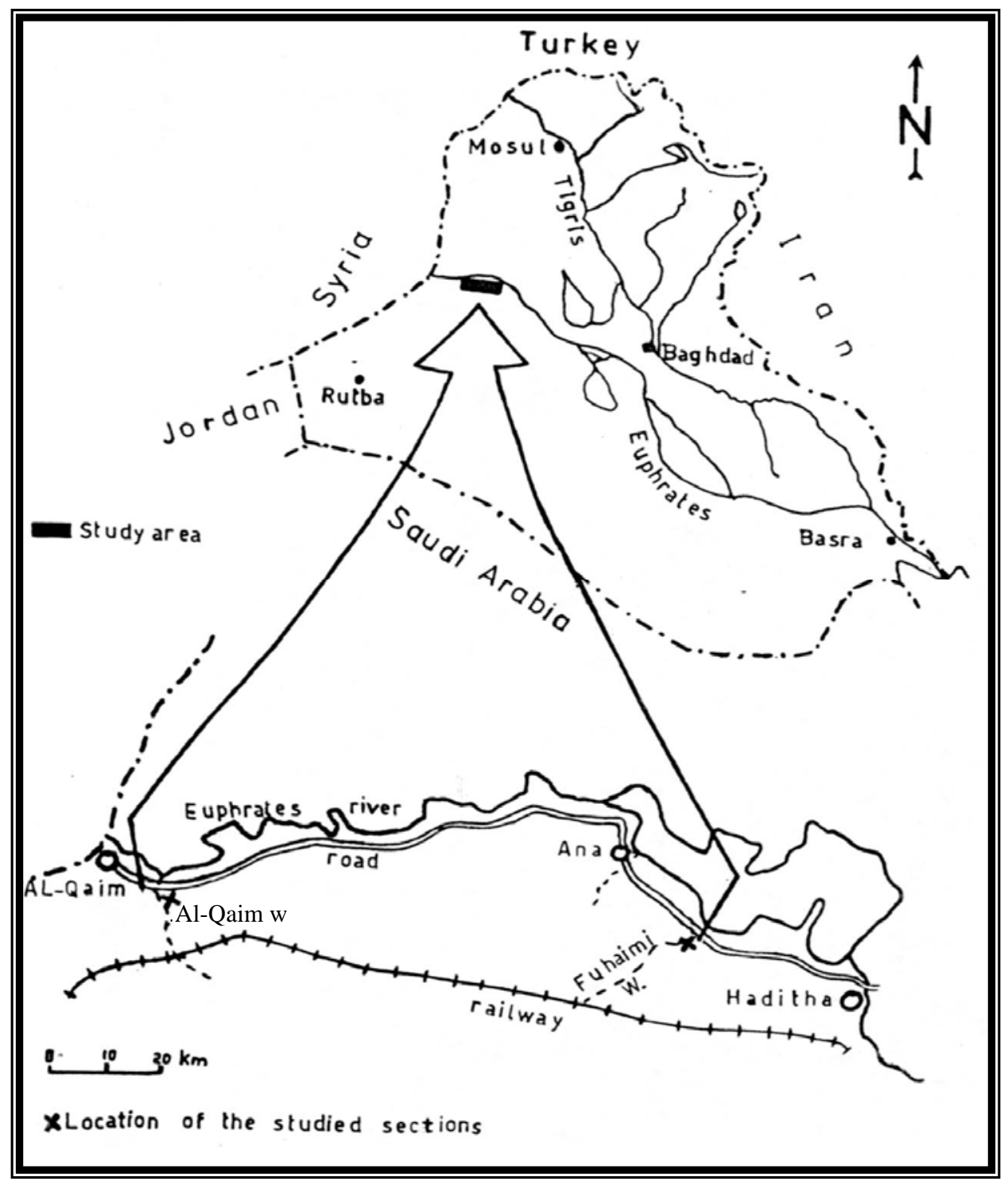

Fig. 1: Location map of the studied area.

\section{STRATIGRAPHY AND SEDIMENTATION}

Very excellent work about the Euphrates Formation (Lower Miocene) in the studied area was carried out through the detailed geological mapping by Fouad et al. (1986). They delt with this formation from structural, stratigraphical, biostratigraphical, 
paleontological and petrographical points of view. Al-Abbasi (1994) made a sedimentological study of the Euphrates Formation at eastern Butma area northwest Iraq. He constructed a depositional model for the Euphrates Formation, where most of the microfacies are proved to be deposited in lagoonal and back reef environments. In addition of these workers, other works were performed, among them; Hopkins (1958), Al-Mubarak (1971), Ctyroky and Karim (1971) and Tyracke and Younan (1975).

Unconformable contact exists between the Euphrates Formation and the underlying Anah Formation (Oligocene) in Anah area. Euphrates Formation was deposited during the Early Miocene transgression that followed the continental erosional period during the most Late Oligocene and Early Miocene (Fouad et al., 1986). The later subdivided the formation into six informal units: conglomeritic, shelly (lower and upper), lower chalky, upper chalky, brecciated and undulated units. In addition to their description, the present work adds other physical descriptive features in Fuhaimi valley like lateral facies change and all the sedimentary structures which have been documented in the present work, (Fig. 2).

The conglomeritic unit, (1.5-5 m), thick is represented by subrounded and rounded pebbles and angular to subangular breccia fragments of older Oligocene carbonates. The fragments range in size from a few millimetres to about two centimetres in diameter. In Fuhaimi valley, the brecciated fragments are composed of light grey to grey colour, tough, fine crystalline carbonate fragments and occasionally containing coral reef clasts.

The shelly unit, (12-20 m), dark grey in colour, fine to medium crystalline, tough and fossiliferous dolomitic limestone. It shows lateral facies changes of arenaceous and finely crystalline dolostones. Cross bedding and ripple marks occur frequently. The fossils are gastropods, pelecypods, oysters and echinoids.

The lower chalky unit (16-22 m), white to pale grey, finely cross laminated, medium tough, thick bedded, fossiliferous dolostone, boring and burrowing are well known, some beds are coquina and comprised by echinoids, pelecypods and gastropods. Some oolitic beds occur as lenses.

The upper chalky unit, $(15 \mathrm{~m})$, pale grey, cross laminated, tough and cross bedded oolitic dolostones overlain by medium tough, thin bedded and fossiliferous dolostone. These beds are overlain by grey, fine cross laminated, tough, thickly bedded dolostone and marly dolostone interbeds with thin green marl.

The brecciated unit, $(8-16.5 \mathrm{~m})$ is characterized by green friable alternating with thick bedded white dolostone, marly dolostone and dolomitic limestone at the lower part, whereas the upper part is represented by alternations of pale yellowish green, thick and thin beds of marl and marly dolostones. Slumping and syndepositional folding and faulting occur occasionally. Brecciation, load cast and flow structures are also present.

The undulated unit, $(0.5-5.5 \mathrm{~m})$, pale grey, cross laminated, thin bedded, fossiliferous limestone with scarce stromatolites. The undulations look like dish or tepee structure. Conformable contact with the overlying Nfayil unit is observed.

Exposures of the Euphrates Formation in Al-Qaim valley (Fig. 3) reflects alternation of various arenaceous lithologic associations; arenaceous limestone, arenaceous marly limestone, arenaceous marl ...etc. They have various colours ranging from grey, pale grey to yellowish grey. Many sedimentary structures which reflects supratidal zone environment have been documented, like crystal mold and relicts of original gypsum within calcite nodules, i.e. calcite after gypsum. This habit of evaporite 
has been considered as a diagnostic feature of hypersaline lagoonal tidal flat associations (Wood and Wolf, 1969; Phleger, 1969; Bosellini and Hardie, 1973; West, et al., 1980). Although may occurs frequently in the outer bar or shoal facies (Al-Naqib et al., 1986). Modern analogue of such feature and apart from typical association of evaporite and dolomite in the sabkha of the Arabian Gulf, evaporite crystals few millimeters in length occur in the upper intertidal zone (Leeder, 1982).

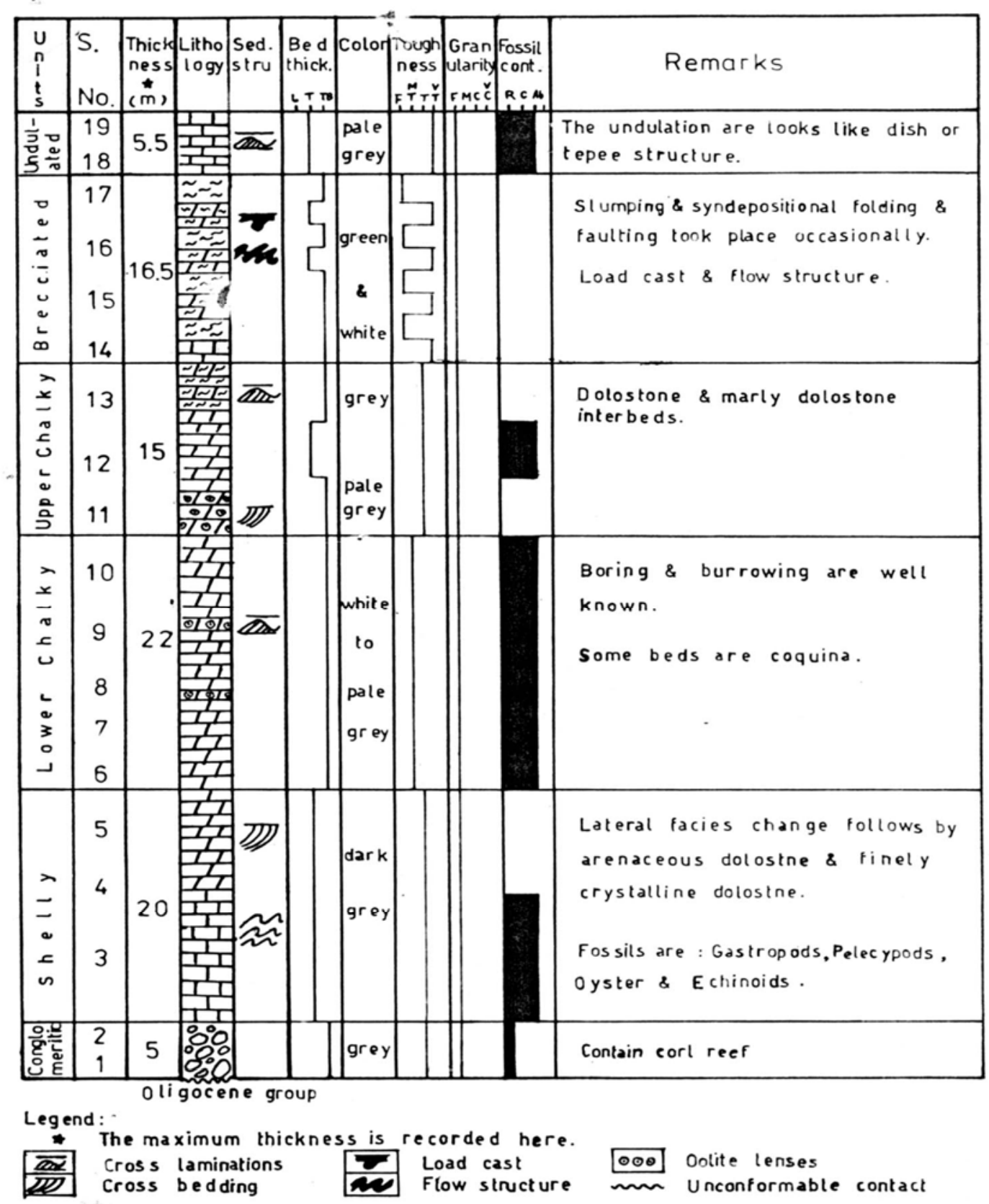

Fig. 2: Geological section of the Euphrates Formation in Fuhaimi valley. 


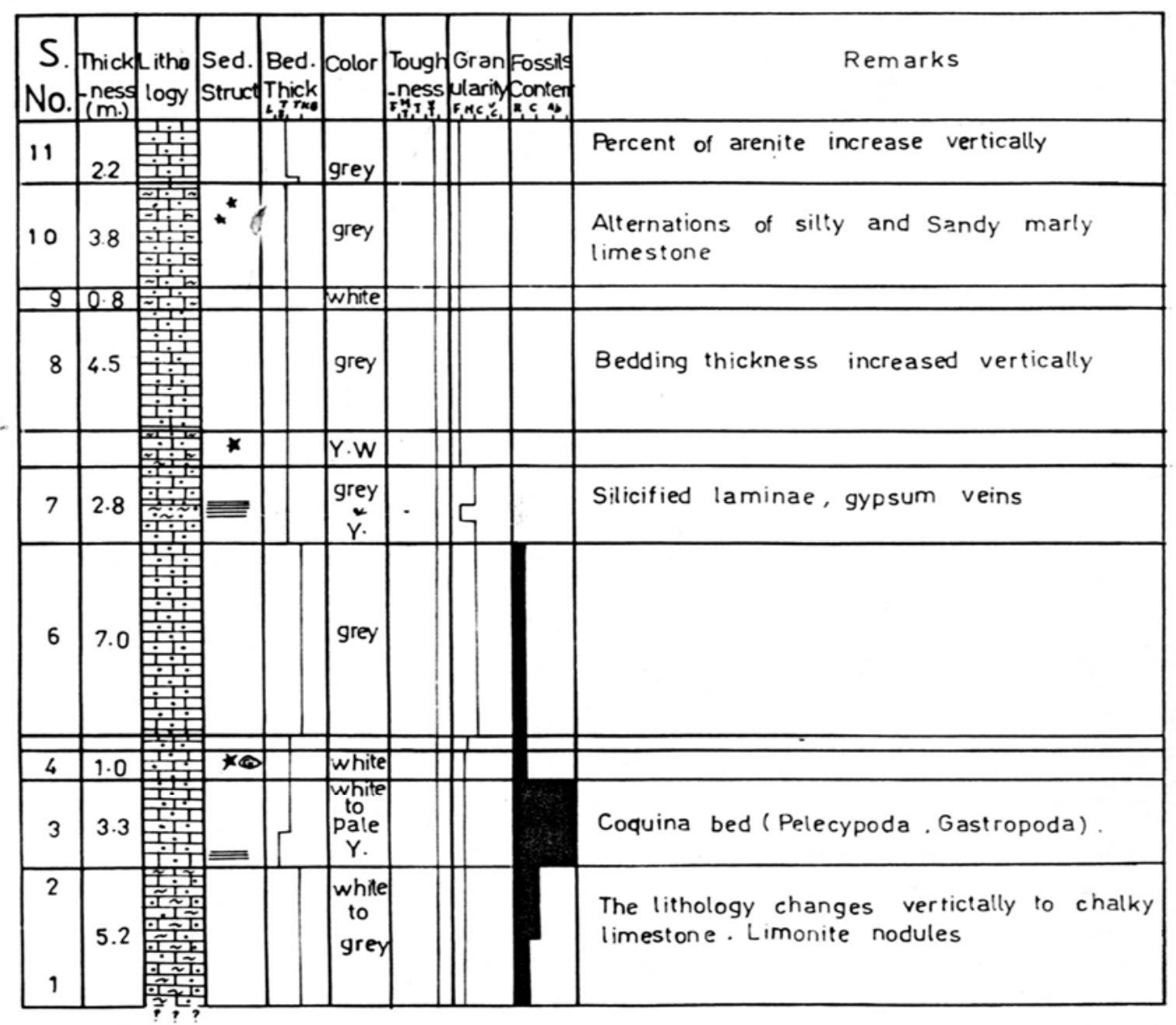

Legend :

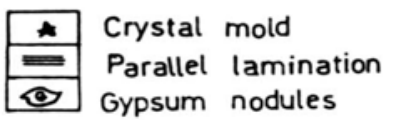

Fig. 3: Geological section of the Euphrates Formation in Al-Qaim valley.

Al-Hashimi and Amer (1985) stated that, the formation according to its wide distribution and relatively long range (whole Early Miocene) has been deposited under various environmental conditions, with diverse microfacies and faunal assemblages. At the early Lower Miocene, the base of the formation at Fuhaimi valley reflects typical coral reef facies, followed by restricted environment (backreef facies). Though at AlQaim area the formation may represent the shallower part of its depositional basin, where at Fuhaimi area, the formation appears to have been deposited under various environmental setting reflected by its numerous microfacies and various sedimentary structures.

\section{MICROFACIES ANALYSIS}

According to the classification of Dunham (1962), thirty thin sections from Fuhaimi and Al-Qaim valleys have been petrographically described in details. Five microfacies have been determined: 
1. Pelletal lime packstone microfacies

This microfacies consists primarily of fecal pellets and the ground mass is composed of microspar and the micrite. The pellet is fine micritic grain, less than $(0.1$ $\mathrm{mm}$ ) in diameter, rounded to oval in shape, black in colour and generally well sorted.

It can be interpreted that the mud feeding animals in the shallower parts produced the fecal pellets in rounded and oval shape (Beales, 1965). The fecal pellets are concentrated in the peritidal zones (quite water) (Flugel, 1982).

This microfacies matched exactely the standard microfacies (SMF-16) which was proposed by Wilson (1975), Flugel (1982), Pomar et al. (1996) and Antoshkina (1998), it is located within Wilson facies zone (FZ-7) representing a shallow warm water with moderate water circulation within the shallow shelf lagoon.

2. Pellitoidal lime grainstone microfacies

Pellitoid can be defined according to Blatt et al., (1972) as a by-product grain which was produced from micritization and rolling of the bioclasts. They are characterized by subrounded shapes and definit ornamentation of original fossils, in addition to its relatively large grain size in comparison with fecal pellet grains.

It is obvious that these grains were passed through two stages: decay and recrystallization, before they became rounded and structurless (Wilson, 1975). Among the evidence, which support this idea, in this microfacies, is the presence of micritized fossils, which is enveloped by thin alternated laminae of black colour micrite. Additionally, the presence of fossil ghosts and remnants of fossil ornamentation's on some pellitoid grains. Accordingly and in agreement with Wilson (1975) and Flugel (1982), this facies could be compared with the (SMF-17) which was deposited in the facies zone (FZ-8) (restricted platforms) where shelf and tidal flats with restricted circulation.

3. Oolitic lime grainstone microfacies

This microfacies consists dominantly of ooids in addition to the presence of bioclasts and some planktonic fauna. The ooides can be defined here as rounded and oval shape grain, which have less than $(2 \mathrm{~mm})$ in diameter. The ooides in this facies is regarded as a normal individual ooides. It is noticed that its nucleous could be a fragment of fossil or dolomite grain. The nucleus is surrounded by more than one envelope, tangential or radiated or both. The groundmass of this facies consists dominantly of sparite.

Most of workers indicated that the presence of ooides must be confined to the disturbed shallow high energy water, In addition to its high calcium and carbonate enrichments (Reeckman and Friedman, 1982; Flugel, 1982). This microfacies could be compared with (SMF - 15) as suggested by Flugel (1982) and Wilson (1975). It is confined to facies zone (FZ - 6) (winnowed edge platform sands) which is characterized by shallow high-energy water.

4. Benthonic lime packstone microfacies

This microfacies consists oftenly of benthonic fauna, particularily milliolids, peneroplidae and rotalids, in addition to ostracods and fragments of algal crusts. The grains in this facies are tangential and compacted, whereas the groundmass is mainly micritic and microspare. This microfacies was affected by dolomitization. It regards as dominant facies among the studied facies. Its presence is confined to the middle part of Euphrates Formation. The abovementioned fossils refer to high diversity in its 
persistence within the formation. According to Brasier (1975) and Gischler and Lomando (1999) this phenomena could be used as strong clue about lagoon or back reef shallow warm zones with normal salinity environment.

On other hand, Moor (1957) found that these fauna could be found in the back reef area and within (15m) depth. Additionally, Bandy (1964) and Murray (1968) found that these fauna could live attached to the shelf marine benthonic grasses which is characterized by relatively low water energy of deposition.

In comparison with the standard microfacies model of Wilson (1975) and Flugel (1982) it can be estimated that this microfacies is a match to the (SMF-18) which is localized between (FZ-7) and (FZ-8) represented by the open and restricted platform respectively.

5. Dolomitized lime mudstone microfacies

It consists primarily of dolomitic micrite and less than (10\%) skeletal bioclasts. This facies was suffered from severe dolomitization, which changes most, if not all, the primary features of the constituting grains. Dolomite crystals are characterized by rhomboidal shapes, small uniform size and homogenouse internal structure.

This microfacies is very common in the Euphrates Formation, especially in its lower parts. It could be compared with the (SMF-22) which is localized within the facies zone (FZ-8), which defines a restricted platform (Wilson. 1975; Flugel, 1982).

\section{SOME GEOCHEMICAL ASPECTS}

Twenty-four samples were analyzed chemically for major oxides in the Laboatory of Research Center for Environment and Water Resources. $\mathrm{CaO}$ and $\mathrm{MgO}$ analyzed by titration with EDTA, $\mathrm{Al}_{2} \mathrm{O}_{3}$ and $\mathrm{Fe}_{2} \mathrm{O}_{3}$ by colourimetery, I.R. by gravimetery and $\mathrm{Na}_{2} \mathrm{O}$ and $\mathrm{K}_{2} \mathrm{O}$ by flamephotometer.

The Euphrates Formation constitutes varied carbonates; dolostone, dolomitic limestone, limestone and marl. The major oxides represent their main components, which are present in various mineral phases; calcite, dolomite as well as insoluble residue (clay minerals and silica).

Table (1) shows the oxide concentration in the units of the Euphrates Formation. shelly, lower chalky and upper chalky units constitute $\mathrm{CaO}$ between (23-37)\%. These concentrations are influenced by the composition of dolostone mainly. The variation in dolomitization among the above three units reflects a range of $\mathrm{MgO}$ concentration (13-23)\%.

$\mathrm{Al}_{2} \mathrm{O}_{3}, \mathrm{Fe}_{2} \mathrm{O}_{3}, \mathrm{Na}_{2} \mathrm{O}$ and $\mathrm{K}_{2} \mathrm{O}$ represent the clay minerals contents (Weaver and Pollard, 1975). As well as, $\mathrm{Fe}_{2} \mathrm{O}_{3}$ found as iron oxides phases and/or replacing $\mathrm{MgO}$ in dolomite (Scott, 1986). In spite of relatively low concentration of both aluminum and iron in the carbonates, they may be assigned for the effect of the depositional environment (Naida et al., 1971). $\mathrm{Na}_{2} \mathrm{O}$ may be found as a secondary mineral or adsorbed on the clay mineral surfaces (Bear, 1965). Insoluble residue represents the clay minerals and silica as fine grain quartz.

There is a similarity in the covariation of $\mathrm{Al}_{2} \mathrm{O}_{3}, \mathrm{Fe}_{2} \mathrm{O}_{3}, \mathrm{Na}_{2} \mathrm{O}, \mathrm{K}_{2} \mathrm{O}$ and insoluble residue among the three units. It is clear that the concentrations have lower percentages than the brecciated and undulated units. These chemical characterization which reflect high $\mathrm{MgO}$ and low content of clay minerals and detritus may be related to the conditions 
of the depositional environments of the shelly, lower chalky and upper chalky units. They were quiet shallow environments with restricted circulation.

Table 1: Major oxide and insoluble residue contents of the Euphrates units (range and average, wt. \%).

\begin{tabular}{|c|c|c|c|c|c|}
\hline \multirow[b]{2}{*}{ Oxides } & \multicolumn{2}{|r|}{$\mathbf{U}$} & \multirow{2}{*}{$\begin{array}{c}\text { n i t } \\
\text { Upper } \\
\text { Chalky } \\
23\end{array}$} & \multicolumn{2}{|l|}{$\mathbf{s}$} \\
\hline & Undulated & Brecciated & & $\begin{array}{l}\text { Lower } \\
\text { chalky }\end{array}$ & Shelly \\
\hline $\mathrm{CaO}$ & $\begin{array}{c}44.56-52.57 \\
(48.49) \\
\end{array}$ & $\begin{array}{c}24.39-42.15 \\
(32.88)\end{array}$ & $\begin{array}{c}23.47-34.47 \\
(32.46) \\
\end{array}$ & $\begin{array}{c}27.27-37.14 \\
(30.33) \\
\end{array}$ & $\begin{array}{c}25.31-32.55 \\
(32.04)\end{array}$ \\
\hline $\mathrm{MgO}$ & $\begin{array}{c}0.32-5.65 \\
(2.49)\end{array}$ & $\begin{array}{c}9.28-20.66 \\
(14.73) \\
\end{array}$ & $\begin{array}{c}16.05-22.03 \\
(19.11) \\
\end{array}$ & $\begin{array}{c}14.35-23.07 \\
21.21) \\
\end{array}$ & $\begin{array}{c}13.29-20.23 \\
(19.84)\end{array}$ \\
\hline $\mathrm{Al}_{2} \mathrm{O}_{3}$ & $\begin{array}{c}1.20-0.92 \\
(1.43)\end{array}$ & $\begin{array}{c}1.02-1.69 \\
(1.66)\end{array}$ & $\begin{array}{c}0.51-0.72 \\
(0.64)\end{array}$ & $\begin{array}{c}0.43-0.76 \\
(0.52)\end{array}$ & $\begin{array}{c}0.77-1.02 \\
(0.97)\end{array}$ \\
\hline $\mathrm{Fe}_{2} \mathrm{O}_{3}$ & $\begin{array}{c}0.43-0.92 \\
(0.62)\end{array}$ & $\begin{array}{c}0.70-1.62 \\
(0.82)\end{array}$ & $\begin{array}{c}0.33-0.53 \\
(0.38)\end{array}$ & $\begin{array}{c}0.52-0.65 \\
(0.56)\end{array}$ & $\begin{array}{c}0.39-0.41 \\
(0.40)\end{array}$ \\
\hline $\mathrm{Na}_{2} \mathrm{O}$ & $\begin{array}{c}0.78-0.92 \\
(0.81)\end{array}$ & $\begin{array}{c}1.09-1.51 \\
(1.13)\end{array}$ & $\begin{array}{c}0.32-0.63 \\
(0.44)\end{array}$ & $\begin{array}{c}0.01-0.06 \\
(0.04)\end{array}$ & $\begin{array}{c}0.07-0.21 \\
(0.11)\end{array}$ \\
\hline $\mathrm{K}_{2} \mathrm{O}$ & $\begin{array}{c}0.22-0.32 \\
(0.26)\end{array}$ & $\begin{array}{c}0.28-0.52 \\
(0.34)\end{array}$ & $\begin{array}{c}0.10-0.15 \\
(0.12)\end{array}$ & $\begin{array}{c}0.12-0.28 \\
(0.16)\end{array}$ & $\begin{array}{c}0.07-0.22 \\
(0.12)\end{array}$ \\
\hline I.R. & $\begin{array}{c}2.32-5.72 \\
(2.95)\end{array}$ & $\begin{array}{c}2.78-6.08 \\
(3.49)\end{array}$ & $\begin{array}{c}1.58-3.12 \\
(1.97)\end{array}$ & $\begin{array}{c}1.09-1.83 \\
(1.69)\end{array}$ & $\begin{array}{c}0.97-2.51 \\
(2.09)\end{array}$ \\
\hline L.O.I & $\begin{array}{c}24.21-28.20 \\
(25.63)\end{array}$ & $\begin{array}{c}22.45-24.62 \\
(23.47)\end{array}$ & $\begin{array}{c}18.73-23.04 \\
(20.25)\end{array}$ & $\begin{array}{c}18.55-21.79 \\
(21.21)\end{array}$ & $\begin{array}{c}22.28-26 . \\
(24.62)\end{array}$ \\
\hline
\end{tabular}

$\mathrm{CaO}$ concentration in the brecciated unit is similar to the above three units while $\mathrm{MgO}$ is lower. All the rest oxides and insoluble residue show higher concentrations than the previous three units due to the presence of marl alternated with dolostone. The chemical composition of the brecciated unit reflects an increase in fine clastic materials.

It appears that the undulated unit is limestone, so the $\mathrm{CaO}$ concentration is higher, whereas $\mathrm{MgO}$ concentration is lower. Its insoluble residue content is relatively high which indicates higher proportion of detritus with concomitant decrease of $\mathrm{MgO}$ concentration.

Table (2) shows the R-mode correlation coefficients among the major oxides. $\mathrm{CaO}$ and $\mathrm{MgO}$ covary together with positive correlation due to their presence in the carbonate minerals, although they present in clay minerals but the later is very low in the studied units except the undulated unit. Other oxides $\left(\mathrm{Al}_{2} \mathrm{O}_{3}, \mathrm{Fe}_{2} \mathrm{O}_{3}, \mathrm{Na}_{2} \mathrm{O}, \mathrm{K}_{2} \mathrm{O}\right)$ are correlated together positively, which reflect mostly their presence in clay minerals (Millot, 1970). It is clear that the positive correlation clustered into two groups; the first group is $\mathrm{CaO}$ and $\mathrm{MgO}$ (the carbonates), although they present in clay minerals, and the second group is the detritus (insoluble residue). 
Table 2: R-mode correlation coefficients.

\begin{tabular}{|l|c|c|c|c|c|c|c|c|}
\hline & $\mathbf{C a O}$ & $\mathbf{M g O}$ & $\mathbf{I . R .}$ & $\mathbf{A l}_{\mathbf{2}} \mathbf{O}_{3}$ & $\mathbf{F e}_{\mathbf{2}} \mathbf{O}_{3}$ & $\mathbf{N a}_{\mathbf{2}} \mathbf{O}$ & $\mathbf{K}_{\mathbf{2}} \mathbf{O}$ & L.O.I \\
\hline $\mathrm{CaO}$ & 1 & 0.67 & -0.46 & -0.49 & -0.25 & -0.47 & -0.92 & 0.91 \\
\hline $\mathrm{MgO}$ & & 1 & -0.36 & 0.27 & -0.25 & -0.55 & -0.83 & 0.70 \\
\hline I.R. & & & 1 & 0.86 & 0.52 & 0.83 & 0.41 & -0.42 \\
\hline $\mathrm{Al}_{2} \mathrm{O}_{3}$ & & & & 1 & 0.65 & 0.29 & 0.39 & -0.46 \\
\hline $\mathrm{Fe}_{2} \mathrm{O}_{3}$ & & & & & 1 & 0.21 & 0.18 & -0.36 \\
\hline $\mathrm{Na}_{2} \mathrm{O}$ & & & & & & 1 & 0.46 & -0.32 \\
\hline $\mathrm{K}_{2} \mathrm{O}$ & & & & & & & 1 & -0.81 \\
\hline L.O.I & & & & & & & & 1 \\
\hline
\end{tabular}

\section{DEPOSITIONAL HISTORY}

The basal thickly bedded conglomerate in the lower part of the Euphrates Formation is inherited from the erosion of various Oligocene sediments which had been redeposited due to marine transgression and the beginning of the new sedimentary cycle at the Early Miocene. Hence, the fossils content of the reworked pebbles belongs to the Oligocene formations, whereas, the fossils which had been identified within the cementing material represent the early Miocene period.

During the Early Miocene, and soon after the deposition of the basal conglomerate, the marine environment became relatively quite with warm and shallow water. Therefor, pelletal lime packstone facies was deposited in open platform zone (shelf lagoon), where the wave enargy was relatively intermediate. Then, the pelletoidal lime grainstone facies was followed reflecting relative restricted platform zone environment. The high MgO concentration and low content of clay minerals and detritus also assure this.

After that, oolitic lime grainstone facies was deposited, which indicates shallow, warm and high water energy marine environment. The fourth facies is represented by bentonic lime packston facies, which assigned to the sediments of shallow warm lagoon environment. This environment could be alternated between open platform and restricted platform respectively. The final phase of the later microfacies represented in the study area by restricted platform environment, which reflected by dolomitized lime mudstone facies.

\section{CONCLUSION}

In conclusion, the Euphrates Formation in the studied area was deposited in various depositional environment ranging from the shelf, low water energy, restricted and lagoonal environment to the relatively high water energy open marine environments. The variations are detected by both microfacies and geochemical analysis. 


\section{REFERENCES}

Al-Abbasi, Z.A., 1994. Sedimentological study of the Jeribe and Euphrates Formations at Sheikh-Ibrahim and eastern Butma areas north-west Iraq. Unpublished M. Sc. Thesis, University of Mosul, Mosul-Iraq. 128p. (In Arabic)

Al-Hashimi, H. and Amer, R., 1985. Tertiary Microfacies of Iraq, D.G. of Geol. Surv. and Mineral Investigation, National Library catalogue No. 1655, Baghdad 57p.

Al-Mubarak, M., 1971. Final geological report of Euphrates valley, NIMCO Report, S.O.M. Library, No. 677, Baghdad.

Al-Naqib. S.Q., Aghwan, T.A. and Amin, M.A., 1986. Sedimentology of the Zor Hauran Formation. Jour. Geol. Soci. Iraq, 19(3), pp.155-180.

Antoshkina, A., 1998. Organic builders and reefs on the paleozoic carbonate platform margin, Pechora-Vrale, Russia. Sed. Geol., 118, pp.187-211.

Bandy, O.L., 1964. Foraminiferal biofacies in sediments of Gulf of Bata bano, Cuba, and their geologic significance. Am. Asso. Pet. Geol. Bull., 48, pp.1666-1679.

Beales, F.W., 1965. Diagensis in Pelletted Limestone; (in) Pray, L. C. and Murray, R. C. (ed.) Dolomitization and Limestone diagensis, Symposium, SEPM. Sepc. Publ., 13, 49-70.

Bear, F.E., 1965. Chemistry of the Soil. 2nd edition, Reinhold Publishing Corporation, New York, 515p.

Blatt. H., Middleton. G. and Murray, R., 1972. Origin of Sedimentary Rocks. Englewood Cliffs, New Jersy, 653p.

Bosellini, A. and Hardie, L.A., 1973. Depositional theme of marginal evaporite. Sedimentology, 20, pp.5-27.

Brasier, M.D., 1975. The ecology and distribution of resent foraminifera from the reef and shoals around Barbuda, West Indies. J. Foraminiferal Res., 5, pp.193-210.

Ctyroky, P. and Karim, S.A., 1971. Stratigraphy and Paleontology of Oligocene strata near Anah. Euphrates valley, Western desert, Iraq. NIMCO Report S.O.M. Library, No. 501, Baghdad.

Dunham, R.J., 1962. Classification of Carbonate Rocks According to Depositional Textures, (in) Ham, W. E. (ed.) Classification of Carbonate Rocks, A Symposium. Am. Assoc. Petr. Geol. Mem. 1. Tulsa, Oklahoma, pp.108-121.

Flugel, E., 1982. Microfacies Analysis of Limestone, Translated by Christen, K., Springer-Verlag, Berlin, 633p.

Fouad, S.F., Al-Marsoumi, A.H., Saleh, F.S., Hasan, F. A. and Nanno, H.O., 1986. Detailed Geological Survey of Anah area. D.G. of Geol. Surv. and Min. Investig., Report S.O.M., Baghdad.

Gischlor, E. and Lomando, A. J. 1999. Recent sedimentology facies of isolated carbonate platform, Belize-Yucatan system, Central America. J. Sed. Res., SEPM, 6(3), pp.747-763.

Hopkins, D.T., 1958. Note on the Zoning of the Euphrates Limestone in Anah valley No. 2, IPC Report, INOC Library, Baghdad.

Leeder, M.R., 1982. Sedimentology: Process and product. George Allen and Unwin, London, 344p.

Millot, G., 1970. Geology of Clays. Springer-Verlag, New York, 429p.

Moore, W.E., 1957. Ecology of Recent Foraminifera in Northern Florida Kays. Am. Ass. Pet. Geol. Bull., 41(4), pp.727-741. 
Murray, J.W., 1968. Living Foraminifera of Lagoons and Estuaries. Micropaleantology, 14(4), pp.435- 455.

Naida, A.S., Burrell, D.C. and Hood, D.W., 1971. Clay Mineral Composition and Geological Significance of Some Beaufort Sea Sediments. Jour. Sed. Petrol., 41, pp.691-694.

Phleger, F.B., 1969. A Modern Evaporite Deposit in Mexico. Am. Asso. Pet. Geol. Bulletin, 53, pp.824-829.

Reeckmann, A. and Friedman, G.M., 1982. Exploration for Carbonate Petroleum Reservoirs, John Wiley and Sons, New York, 213p.

Scott, K.M., 1986. Elements Partitioning into Mn and Fe oxides Derived from dolomitic Shale hosted deposits. NorthWest Queen-land, Australia. Chemical Geology, 57, pp.395-414.

Tyracek, J. and Younan, Y., 1975. Regional Survey of Western Desert between T-l Oil Pumping Station and valley Hauran, Western Iraq. NIMCO Report. S.O.M. Library, No. 673, Baghdad.

West, I.M., Brandon, A.B. and Smith, M., 1980. A Tidal-flat Evaporitic Facies in the Visean of Ireland. J. Sed. Petrol., 38, pp.1079-1093.

Wilson, J.L., 1975. Carbonate Facies in Geologic History, Springer-Verlag, Berlin. 471p.

Wood, G.V. and Wolf, M.J., 1969. Sabkha cycle in the Arab/Darb Formation of the Trucial Coast of Arabia. Sedimentology, 12, pp.165-191. 